Provided for non-commercial research and education use. Not for reproduction, distribution or commercial use.

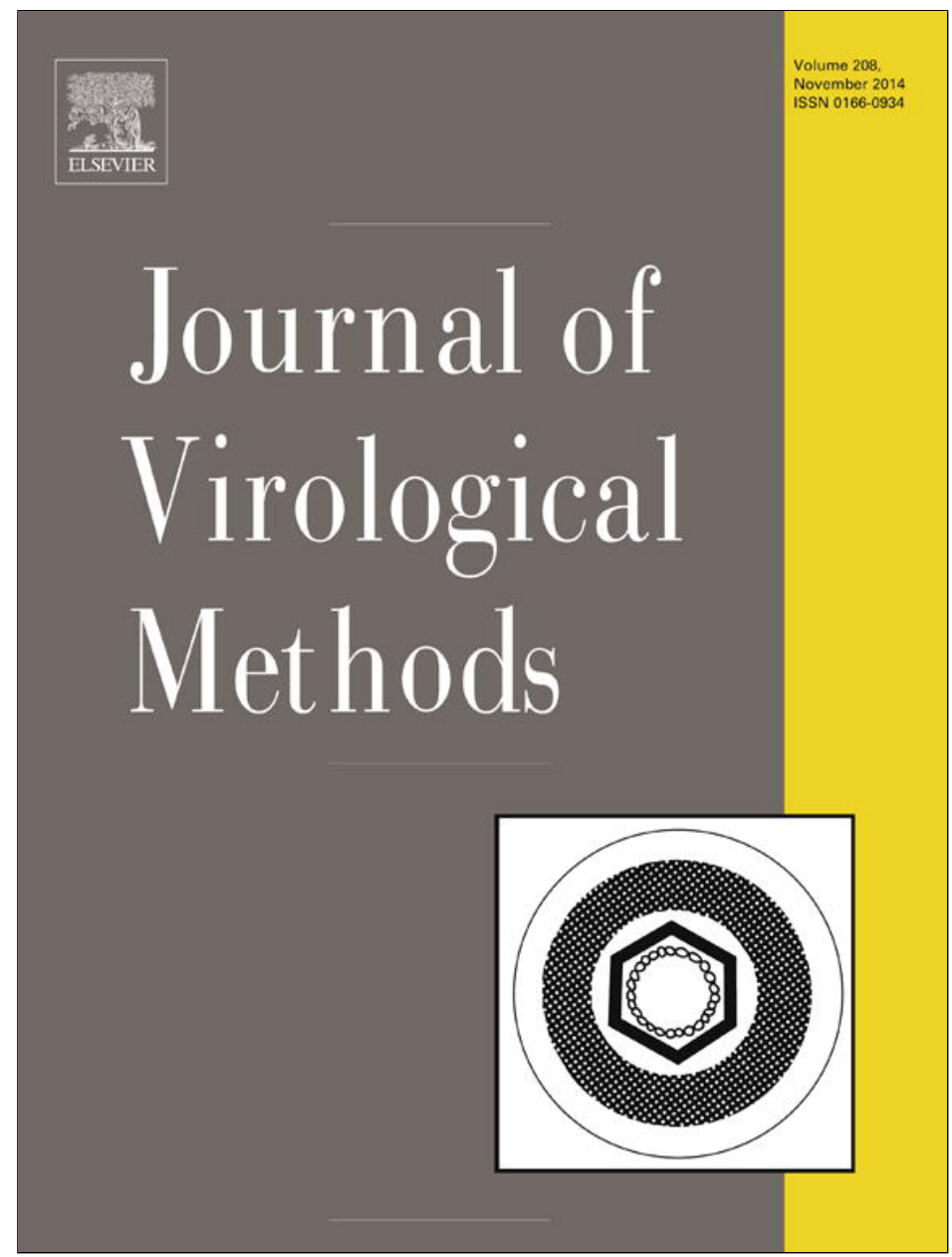

This article appeared in a journal published by Elsevier. The attached copy is furnished to the author for internal non-commercial research and education use, including for instruction at the authors institution and sharing with colleagues.

Other uses, including reproduction and distribution, or selling or licensing copies, or posting to personal, institutional or third party websites are prohibited.

In most cases authors are permitted to post their version of the article (e.g. in Word or Tex form) to their personal website or institutional repository. Authors requiring further information regarding Elsevier's archiving and manuscript policies are encouraged to visit:

http://www.elsevier.com/authorsrights 


\title{
A degenerate pair of primers for simultaneous detection of four alpha- and betanecroviruses
}

\author{
C.M.R. Varanda ${ }^{\mathrm{a}, *}$, J.M.S. Cardoso ${ }^{\mathrm{b}}$, M.D.M. Oliveira ${ }^{\mathrm{a}}$, S. Oliveira ${ }^{\mathrm{c}}$, \\ M.I.E. Clara ${ }^{a}$, M.R.F. Félix ${ }^{a}$ \\ a Laboratório de Virologia Vegetal, Instituto de Ciências Agrárias e Ambientais Mediterrânicas, Universidade de Évora, Apartado 94, 7002-554 Évora, \\ Portugal \\ b IMAR-CMA, Departamento de Ciências da Vida, Universidade de Coimbra, 3004-517 Coimbra, Portugal

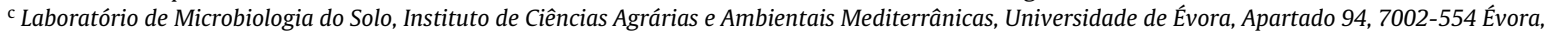 \\ Portugal
}

\section{Article history:}

Received 21 April 2014

Received in revised form 30 July 2014

Accepted 1 August 2014

Available online 10 August 2014

\section{Keywords:}

Olive trees

OLV-1

OMMV

TNV-A

TNV-D

\begin{abstract}
A B S T R A C T
The high infection levels due to Olive latent virus 1 (OLV-1), Olive mild mosaic virus (OMMV) (alphanecrovirus) and Tobacco necrosis virus D (TNV-D) (betanecrovirus) in Portuguese olive orchards prompted us to develop a rapid PCR-based assay for the simultaneous detection of these viruses aimed at the sanitary selection and marketing of plant material in compliance with European Union regulations. A pair of degenerate oligonucleotide primers, parRdRp5' and parCoat3' was designed based on conserved regions located in the RNA-dependent RNA polymerase (RdRp) and coat protein (CP) genes of these viruses and one other alphanecrovirus, Tobacco necrosis virus A. Its use in RT-PCR assays generated a product of $c a .2000 \mathrm{bp}$ for the 4 viral species tested. These primers were compared with virus specific primers in multiplex RT-PCR, and identical results were obtained. Its application to dsRNA extracted from 54 olive field growing trees originated the expected $c a$. $2000 \mathrm{bp}$ amplicon in 17 trees. The virus identity was determined by sequencing the cloned RT-PCR products. No TNV-A was found.

The RT-PCR assay using the degenerate primers described in this study were shown to be reliable in detecting any of the above-mentioned alpha- and betanecroviruses, and it is as sensitive as that which uses virus specific primers in multiplex assays. Therefore, this assay is well suited for the rapid screen of virus-free plant material in selection and improvement crop programmes. Additionally, it has the potential to reveal virus diversity and the presence of new viruses, provided the RT-PCR generated amplicon is further sequenced.
\end{abstract}

C 2014 Elsevier B.V. All rights reserved.

\section{Introduction}

European Union regulations, namely the Council Directive 92/34/EEC and Commission Directive 92/34/EEC regarding the Conformitas Agraria Communitatis category of marketing plant material, states that olive plants must be free of all viruses as they are considered harmful. In order to examine the health status of olive orchards, appropriate and sensitive viral diagnostic tools have been developed for certification purposes, and cultivar improvement programmes have been initiated in several countries. In general, considerable levels of viral infection have been detected in many regions, including Portugal. In this country, extensive field surveys

\footnotetext{
* Corresponding author. Tel.: +351 266760851; fax: +351 266760828. E-mail address: carlavaranda@uevora.pt (C.M.R. Varanda).
}

have revealed Olive latent virus 1 (OLV-1), Olive mild mosaic virus (OMMV) and Tobacco necrosis virus D (TNV-D) as predominant, reaching infection levels of 31\%, with OMMV the most abundant virus (Saponari et al., 2002; Varanda et al., 2006, 2010; El Air et al., 2011). These viruses have several natural hosts. OLV-1 was first detected in olive (Gallitelli and Savino, 1985), then in citrus (Martelli et al., 1996), tulips (Kanematsu et al., 2001), and recently in tomato plants (Borodynko et al., 2010). TNV-like viruses, that were able to be assigned to TNV-D or TNV-A, have been detected in herbaceous plants such as tobacco, tulip, bean, cucumber and potato, as well as woody crop plants such as pear and apple, citrus, grape (Kassanis, 1970; Kurstak, 1981) and olive (Félix and Clara, 2002b). OMMV was identified for the first time in olive (Cardoso et al., 2005) and genomic sequences of OMMV, published in the Genbank database, were recovered from tulips affected by the Augusta disease, leading to its identification as the causal agent of that disorder (Pham et al., 2009). 
Mixed infections of these three viruses occur naturally quite frequently (Félix and Clara, 2002a; Varanda et al., 2010). These alphaand betanecroviruses share important similarities. OMMV amino acid CP sequence shows $85.1 \%$ identity with that of TNV-D (Cardoso et al., 2009) and its RNA-dependent RNA polymerase (RdRp) has 91.2\% identity with that of OLV-1 (Félix et al., 2005). In fact, differentiation between OMMV and TNV-D isolates is only possible through PCR-based assays using specific primers (Varanda et al., 2010) or genome sequencing.

The main purpose of this study was to design a single pair of degenerate primers to be used in a RT-PCR assay for a sensitive, rapid and reliable detection of either OLV-1, OMMV, TNV-D or TNV-A, applicable to plant health evaluation when the identification of the infecting species is not required, as is often the case of crop improvement programmes, which would additionally offer the opportunity for detecting the presence of new viruses or isolates by carrying out an extra sequencing step.

\section{Materials and methods}

OLV-1, OMMV, TNV-D and TNV-A isolates characterised previously (Félix et al., 2005; Cardoso et al., 2005, 2009; Meulewaeter et al., 1990) were maintained in the experimental host plants Chenopodium murale and Nicotiana benthamiana, and used as positive controls. Inoculated plants were maintained for 2-3 weeks in a growth chamber with a $14 \mathrm{~h}$ photoperiod at $22-24^{\circ} \mathrm{C}$. Total RNA was extracted from $100 \mathrm{mg}$ of symptomatic herbaceous plants using the RNeasy Plant Mini Kit (Qiagen, Hilden, Germany) in accordance with the manufacturer's instructions.

DsRNA extracted from the fruits and stems of 54 olive field trees whose sanitary status concerning OLV-1, OMMV and TNV-D had already been determined (Varanda et al., 2010) were used in this study.

About $1 \mu \mathrm{g}$ of total RNA, or $1 \mu \mathrm{g}$ of denatured dsRNA, was used in a $20 \mu \mathrm{L}$ reaction for cDNA synthesis containing $200 \mathrm{U}$ of M-MLV Reverse Transcriptase (Invitrogen, Carslbad, USA) in the presence of random hexamers (Promega, Madison, USA) and $1 \times$ first strand buffer (Invitrogen, Carlsbad, USA), in accordance with the manufacturer's instructions. For PCR amplification, two degenerate primers (parRdRp5': 5'-CCWGCWCCSMGGGTKATWCARC-3' and parCoat $3^{\prime}$ : 5'-TATCCSGCGTAWGGWGGGAAWKT-3') were designed based on conserved regions among published genomic sequences of OLV-1 isolates (OLV-1: NC_001721 and OLV-1 ${ }^{\mathrm{P}}$ : DQ083996), OMMV wild type (NC_006939), TNV-D isolates (TNV-D: D00942 and TNV-D ${ }^{\mathrm{H}}$ : NC_003487) and TNV-A isolates (TNV-A: NC_001777 and TNV-A ${ }^{C}$ : AY546104) (Fig. 1) in order to enable the PCR amplification of a single and similarly sized genomic fragment from any of these viral species.

The size of the RT-PCR fragment (parRdRpCoat) is predicted to be ca. $2035 \mathrm{bp}$ for OMMV, OLV-1 and TNV-A and ca. $2070 \mathrm{bp}$ for TNV-D, representing about $55 \%$ of the complete genomes.

One $\mu$ l of obtained cDNA was used in PCR carried out in $20 \mathrm{mM}$ Tris- $\mathrm{HCl} \mathrm{pH} 8.8,10 \mathrm{mM} \mathrm{KCl}, 10 \mathrm{mM}\left(\mathrm{NH}_{4}\right) 2 \mathrm{SO}_{4}, 2 \mathrm{mM} \mathrm{MgSO}$,
$0.1 \%$ Triton X-100, $0.1 \mathrm{mgml}^{-1}$ BSA, $0.2 \mathrm{mM}$ dNTPs, $0.5 \mu \mathrm{M}$ of each primer and $2.5 \mathrm{U}$ of Taq DNA Polymerase (Fermentas, Ontario, Canada) in a total volume of $50 \mu \mathrm{l}$. Amplification was carried out in a Thermal Cycler (BioRad, Hercules, USA) at $94^{\circ} \mathrm{C}$ for $1 \mathrm{~min}, 35$ cycles at $94^{\circ} \mathrm{C}$ for $1 \mathrm{~min}, 55^{\circ} \mathrm{C}$ for $1 \mathrm{~min}$ and $72^{\circ} \mathrm{C}$ for $2.5 \mathrm{~min}$, and a final extension step of $72^{\circ} \mathrm{C}$ for $10 \mathrm{~min}$. Amplified products were analysed using agarose gel electrophoresis.

RT-PCR products were purified using GFX PCR DNA Purification kit (GE Healthcare Biosciences, Buckinghamshire, UK) and cloned into pGEM-T easy vector (Promega, Madison, USA), in accordance with the manufacturer's instructions. Plasmid DNA was extracted from $E$. coli cells using GenElute ${ }^{\mathrm{TM}}$ HP Plasmid Miniprep kit (Sigma, Missouri, USA) in accordance with the manufacturer's instructions, after growing cells in low-salt LB medium (1\% tryptone, $0.5 \%$ yeast extract, $0.5 \% \mathrm{NaCl}, \mathrm{pH} 7.5$ ) supplemented with $100 \mu \mathrm{gmL}^{-1}$ of ampicillin and grown over night at $37^{\circ} \mathrm{C}$ and shaken at $175 \mathrm{rpm}$. Ten clones from each cloned PCR product were sequenced in forward and reverse directions, by Macrogen (The Netherlands). Sequence analysis of the resulting amplicon was carried out using BioEdit (Hall, 1999).

\section{Results}

The expected RT-PCR amplification product (about $2000 \mathrm{bp}$ ), using parRdRp5' and parCoat $3^{\prime}$ degenerate primers, was detected in herbaceous plants infected with any of the TNV-D, OLV-1, OMMV and TNV-A viruses used as positive controls (Fig. 2a). Sequencing results of the cloned amplicons confirmed the identity of each infecting virus.

The use of this test using the degenerate primers to dsRNA templates extracted from 54 olive trees RT-PCR tests demonstrated clearly that 17 of these trees were infected with the alpha- and betanecrovirus referred above (Fig. $2 \mathrm{~b}$ ). Cloning and sequencing these 17 PCR products revealed the presence of OMMV in 15 olive trees, OLV- 1 in 12 trees and TNV-D in 4 trees, and mixed infections in 10 of them. This is in complete agreement with the findings of previous studies, in which single and multiplex RT-PCR assays were carried out using the same trees (Varanda et al., 2010). No TNV-A was detected in any of the sequenced clones.

\section{Discussion}

The present study shows that the use of the degenerate primers designed, in RT-PCR, results in an assay as sensitive and reliable in detecting the viruses under test as the assay using the three sets of primers specific for each virus. Yet it has additional advantages as it also detects TNV-A, it is more rapid, results are easier to interpret and contamination risks are lessened as only one pair of primers is used. Furthermore, since the assay developed results in a final amplicon that comprises a significant partial sequence of both RdRp and $\mathrm{CP}$ genes, it can be sequenced and further used for phylogenetic analysis, and enables the detection of isolate variability and a range of species with different sequences as well as other viruses
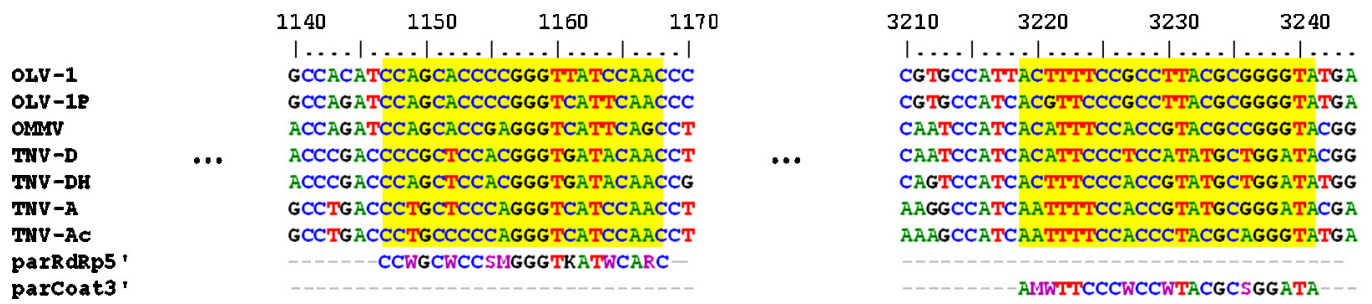

Fig. 1. Multiple sequence alignment showing the genome region of alpha- and betanecroviruses where degenerate primers were designed. The accession numbers of isolates used in the analysis are the following: NC_001721 (OLV-1), DQ083996 (OLV-1P), NC_006939 (OMMV), D00942 (TNV-D), NC_003487 (TNV-DH), NC_001777 (TNV-A), Ay546104 (TNV-Ac). 


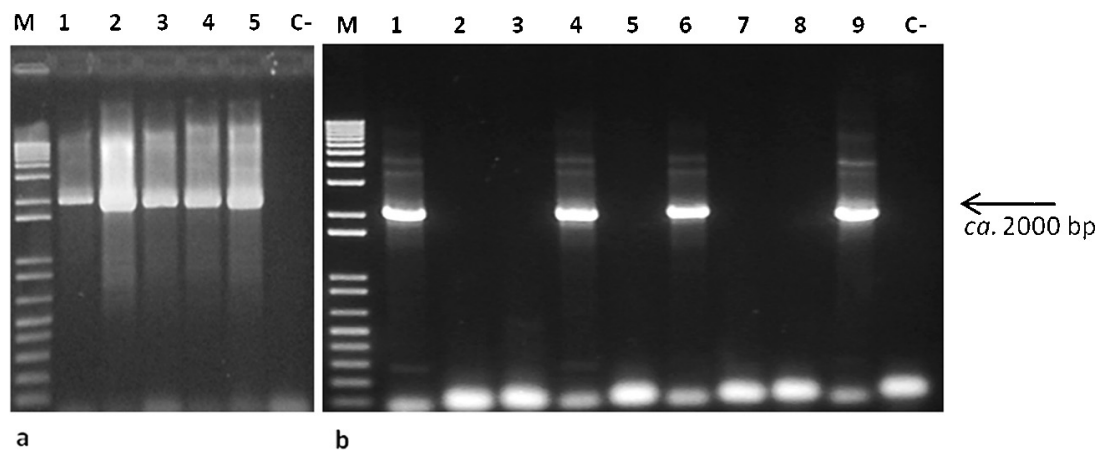

Fig. 2. Products of RT-PCR using primers parRdRp5' and parCoat3', applied to A: total RNA extracted from plant tissues infected with: 1 - TNV-D; 2 - OLV-1; 3 - OMMV; 4 - TNV-A; 5 - TNV-D, OLV-1 and OMMV; and B: dsRNA extracted from 9 olive trees: Lanes 1-9 - olive trees; M - $1 \mathrm{~kb}$ plus DNA ladder (Invitrogen); C - uninfected plants. Arrow indicates the approximate position and the size of the amplicon.

previously unknown, as observed by other authors (Colinet et al., 1995). This is of particular interest for diversity and epidemiological studies of the viruses tested in this study, as it was found that such phylogenetic analysis generates the same tree topology as that which is based on the complete RdRp and CP sequences (data not shown).

The RT-PCR assay using the degenerate pair of primers is especially useful for virus free certification of $O$. europaea, as required by EU directive 93/48 concerning the Conformitas Agraria Communitatis plant material category, and provides support for sanitary selection and improvement programmes of olive or other crops affected by the alpha- and betanecroviruses tested in this study. In fact, this assay was found to be as sensitive, rapid and reliable as multiplex RT-PCR assays. Its application to epidemiological analysis is expected to contribute towards providing an understanding of the high level of dissemination of these viruses in nature.

\section{Acknowledgements}

The authors would like to thank Dr. Meulewaeter (Bayer CropScience, Belgium) for providing a sample of purified TNVA. The authors are grateful to Mrs. Maria Mário Azedo for technical assistance. Carla M. R. Varanda and Joana M.S. Cardoso received post-doctoral fellowships from the Foundation for Science and Technology (FCT): SFRH/BPD/76194/2011 and SFRH/BPD/73724/2010, respectively, funded by QREN - POPH Typology 4.1 - co-funded by MES National Funding and The European Social Fund. Mônica D. M. Oliveira received a post-doctoral fellowship from the Coordenação de Aperfeiçoamento de Pessoal de Nível Superior (CAPES): CsF/2581/31-2. This study was funded by FEDER and national sources, as part of the Programa Operacional Regional do Alentejo (InAlentejo) Operation: ALENT07-0262-FEDER-001871/Laboratório de Biotecnologia Aplicada e Tecnologias Agro-Ambientais, and the FCT under the Strategic Project PEst-OE/AGR/UI0115/2014.

\section{References}

Borodynko, N., Hasiów-Jaroszewska, B., Pospieszny, H., 2010. Identification and characterization of an Olive latent virus 1 isolate from a new host: Solanum lycopersicum. J. Plant Pathol. 92, 789-792.
Cardoso, J.M.S., Félix, M.R., Clara, M.I.E., Oliveira, S., 2005. The complete genome sequence of a new necrovirus isolated from Olea europaea L. Arch. Virol. 150, $815-823$.

Cardoso, J.M.S., Félix, M.R., Clara, M.I.E., Oliveira, S., 2009. Complete genome sequence of a Tobacco necrosis virus D isolate from olive trees. Arch. Virol. 154, 1169-1172.

Colinet, D., Kummert, J., Duterme, O., Lepoivre, P., 1995. Detection of plant viruses by PCR using group or virus specific primers (potyviruses, bymoviruses). Bull. OEPP/EPPO Bull. 25, 289-299.

El Air, M., Mahfoudi, N., Digiaro, M., Najjar, A., Elbeaino, T., 2011. Detection of oliveinfecting viruses in Tunisia. J. Phytopathol. 159, 283-286.

Félix, M.R., Clara, M.I.E., 2002a. Virus incidence in four Olea europaea cultivars evaluated by mechanical inoculation and immunological assays. Acta Hortic. 586, $721-724$.

Félix, M.R., Clara, M.I.E., 2002b. Two necrovirus isolates with properties of Olive latent virus 1 and of Tobacco necrosis virus from olive in Portugal. Acta Hortic. 586, 725-728

Félix, M.R., Cardoso, J.M.S., Oliveira, S., Clara, M.I.E., 2005. Viral properties, primary structure and phylogenetic analysis of the coat protein of an Olive latent virus 1 isolate from Olea europaea L. Virus Res. 108, 195-198.

Gallitelli, D., Savino, V., 1985. Olive latent virus 1, a single RNA spherical virus isolated from olive in Apulia (southern Italy). Ann. Appl. Biol. 106, 295-303.

Hall, T.A., 1999. BioEdit: a user-friendly biological sequence alignment editor and analysis program for Windows 95/98/NT. Nucleic Acids Symp. Ser. 41, 95-98.

Kanematsu, S., Taga, Y., Morikawa, T., 2001. Isolation of Olive latent virus 1 from tulip in Toyama Prefecture. J. Gen. Plant Pathol. 67, 333-334.

Kassanis, B., 1970. Tobacco Necrosis Virus. CMI/AAB Descriptions of Plant Viruses, 14.

Kurstak, E., 1981. Handbook of Plant Virus Infections and Comparative Diagnosis. Elsevier/North-Holland Biomedical Press, Amsterdam.

Martelli, G.P., Yilmaz, M.A., Savino, V., Baloglu, S., Grieco, F., Guldur, M.E., Greco, N., Lafortezza, R., 1996. Properties of a citrus isolate of olive latent virus 1, a new necrovirus. Eur. J. Plant Pathol. 102, 527-536.

Meulewaeter, F., Seurinck, J., Vanemmelo, J., 1990. Genome structure of Tobacco necrosis virus strain-A. Virology 177, 699-709.

Pham, K., Lemmers, M., Van Doorn, J., Derks, T., 2009. Revision of taxonomy of the virus causing Augusta disease in tulips in The Netherlands. In: Fifth Joint Meeting of the DPG Working Group 'Viruskrankheiten der pflanzen' and the 'Netherlandse kring voor plantevirologie, Hamburg, 8-9 April.

Saponari, M., Alkowni, R., Grieco, F., Pantaleo, V., Savino, V., Martelli, G.P., 2002. Detection of olive-infecting viruses in Mediterranean Basin. Acta Hortic. 586, 787-790.

Varanda, C.M.R., Félix, M.R.F., Leitão, F.,Sismeiro, R., Clara, M.I.E., 2006. Application of reverse transcription-polymerase chain reaction to screen a collection of clones of Olea europaea L. for the presence of necroviruses (Tombusviridae). In: 8th Conference of the European Foundation for Plant Pathology \& British Society of Plant Pathology Presidential Meeting 2006, Copenhagen, Denmark.

Varanda, C.M.R., Cardoso, J.M.S., Félix, M.R.F., Oliveira, S., Clara, M.I.E., 2010. Multiplex RT-PCR for detection and identification of three necroviruses that infect olive trees. Eur. J. Plant Pathol. 127, 161-164. 